\title{
Representation and American Governing Institutions
}

\author{
Bryan D. Jones \\ Heather Larsen-Price \\ John Wilkerson \\ Center for American Politics and Public Policy \\ Department of Political Science \\ University of Washington
}

Paper prepared for delivery at the Southern Political Science Association, January 6-7 2006, Atlanta, GA 


\title{
Representation and American Governing Institutions
}

\author{
Abstract \\ Bryan D. Jones \\ Heather Larsen-Price \\ John Wilkerson \\ University of Washington
}

How well are the priorities of the American public reflected in the policy activities of government? Jones and Baumgartner $(2004 ; 2005)$ report impressive correlations between the priorities of the American public (as assessed by the 'most important problem facing the nation' query in Gallup polls) and the distribution of congressional hearings across policy topics. Here we extend this line of research in an important way. Rather than study only congressional behavior, we incorporate activities from the executive branch as well. We study the extent to which the priorities of the public match the activities of policymakers over nine different channels. These channels are in effect instruments through which policymaking is conducted.

We order these channels by institutional friction (the extent to which institutions act to slow down the transference of public demands into public policy) and by the transparency of the policy activity. We correlate public priorities and policy activities using the datasets of the Policy Agendas and Congressional Bills Projects. We find that as the institutional friction increases, the correlations between public priorities and policy actions decrease, and as transparency increases, these correlations decrease. 


\section{Representation and American Governing Institutions}

The typical approach to the empirical study of representation is to examine the congruence between the policy positions taken by policymakers and the political preferences of the constituents they represent. This can involve studying the policy positions taken by individual legislators as they respond to geographic constituencies, or it can involve the study of the actions of an entire legislative chamber across time, observing responses to changes in aggregate public opinion. In either case, one of two approaches has been followed. Either the researcher studies the representative-represented correspondence on single issues (Soroka and Wlezien, in press), or the researcher aggregates positions across numerous issues to examine the correspondence between general policy liberalism of a constituency with the general policy liberalism of the actions of a legislative body (Erikson, Stimson, and McKuen 2002).

This approach has yielded important results, but it fails to incorporate a critical component of representation. Voters, representatives, and governments all prioritize the problems that public policies are designed to address (Jones and Baumgartner 2005). It matters if voters care most about international security but legislators are focusing on welfare reform. Studying representation issue by issue or by aggregating across a variety of policy areas cannot address this prioritization process. We need to know whether representative and represented are even on the same page of the songbook before we study whether they harmonize.

How well are the priorities of the American public reflected in the policy activities of government? Jones and Baumgartner $(2004 ; 2005)$ report impressive correlations between the priorities of the American public (as assessed by the 'most important problem facing the nation' query in Gallup polls) and the distribution of congressional hearings across policy topics. They further report significant, albeit attenuated, correlations between public priorities and lawmaking. Sulkin (2005) suggests one mechanism by which this occurs, finding that representatives bring policy topics raised in elections by challengers into Congressional deliberations.

Here we extend this line of research in an important way. Rather than study only congressional behavior, we incorporate activities from the executive branch as well. We study the extent to which the priorities of the public match the activities of policymakers over nine different channels. These channels are in effect instruments through which policymaking is conducted. They vary in fundamental nature, but all are central to the policymaking process in the United States. Some are used to announce the priorities of policymakers, such as congressional hearings and the president's state of the union speeches. Others recommend action from one institution (the president) to other institutions. These 
include by-request bills, a device through which the president's legislative program is announced, and solicitor general briefs. We also include coverage from the New York Times and the Congressional Quarterly. The channels are listed in Table 1.

Table 1: Policy Channels

\begin{tabular}{|l|c|c|}
\hline \multicolumn{1}{|c|}{ Policy Instrument } & Records & Period available \\
\hline Congressional hearings & $>70,000$ & 1947 to 2000 \\
\hline US Statutes & 17,044 & 1948 to 2002 \\
\hline Bills introduced in congress & 379,000 & 1947 to 2000 \\
\hline $\begin{array}{l}\text { Executive Orders of the } \\
\text { President }\end{array}$ & 3,675 & 1945 to 2001 \\
\hline $\begin{array}{l}\text { Presidential State of the Union } \\
\text { Addresses (coded by quasi- } \\
\text { sentence) }\end{array}$ & & $1947-2004$ \\
\hline Solicitor General Briefs & $1947-2004$ \\
\hline $\begin{array}{l}\text { By Request Bills (introduced } \\
\text { as part of the president's } \\
\text { legislative program) }\end{array}$ & 12,583 & 1948 to 2002 \\
\hline $\begin{array}{l}\text { Congressional Quarterly } \\
\text { Almanac stories }\end{array}$ & 36,403 & 1946 to 2001 \\
\hline $\begin{array}{l}\text { Random sample of entries } \\
\text { from the New York Times } \\
\text { Index }\end{array}$ & & \\
\hline
\end{tabular}

\section{Transparency and Institutional Friction in Representative Behavior}

We may think of factors that inhibit or facilitate linkages between the correspondences between the policy activities of government and the policy priorities of the public. Here we examine two of these factors: the extent of institutional friction and the transparency of the policy act. Because of the explicit design of American political institutions, considerable friction must be overcome before action will be taken. In effect, governing institutions add costs to the translation of demands into responses (Jones, Sulkin, and Larsen 2003; Jones and Baumgartner 2005). Of course public opinion is only one of many components of the input flow into the policymaking process, but it is a crucial one for democratic governance.

The second component is transparency. We hypothesize that the more transparent the action taken by policymakers, the more likely there will be a correspondence between public priorities and policymaking, for equal levels of institutional friction. Of course any policymaking act may be subject to more or less publicity, but we mean something broader by the term transparency. 
Transparency is a characteristic not of individual acts, but of the operation of institutions.

Table 2 characterizes the policy channels detailed in Table 1 according to the friction they are likely to add to the translation of public opinion into policies, and according to their transparency to participants. We expect the highest level of correspondence between public priorities and policy activities where institutional friction is low and transparency is high; the lowest level of correspondence should occur where friction is high and transparency is low. The off-diagonal cells should be intermediate between these anchors. This approach does not allow us to hypothesize particular rankings among policy channels, but it does allow us to specify that policymaking activities that take place through the channels in the upper left-hand cell will be more closely associated with public opinion than those in the other cells.

Table 2: Channels of Policymaking Classified by Institutional Friction and Transparency

\begin{tabular}{|c|c|c|}
\hline Transparency & \multicolumn{2}{|c|}{ Institutional Friction } \\
\hline & Low & High \\
\hline High & New York Times & Statutes \\
& $\begin{array}{c}\text { State of the Union } \\
\text { Hearings } \\
\text { Bills }\end{array}$ \\
& Executive Orders \\
\hline Low & By Request Bills & Solicitor General Briefs \\
& CQ Stories & \\
\hline
\end{tabular}

\section{Issue Components and Responsive Policy}

Focusing on issue prioritization as a major component of representation leads us to hypothesize that some issues will be better represented in policymaking than others. If people care deeply about an issue generally, it is more likely that a tight connection between policy actions and intensity of feeling on that issue will emerge. Public concern for any issue varies across time, but some issues consistently occupy a higher position in public consciousness than others. This can be clearly seen in Figure 1 . There we plot annualized values of Gallup's Most Important Problem surveys, coded by the nineteen major topic categories of the Policy Agendas Project's system, for the period 1946 through 2001 (for details on this procedure, see Feeley, Jones, and Larsen 2004). Economics and defense issues dominate the public's priorities, with crime, civil rights, energy and health also having considerable visibility at more limited times during the period of study. We expect, then, that there will be considerable variability across issues in how closely the activities of government correspond to the priorities of the public, and that this variation approximates the general importance of the issue for the public. 
Figure 1: Most Important Problem coded by Policy Agendas Project Major Topic Categories, 1946-2001

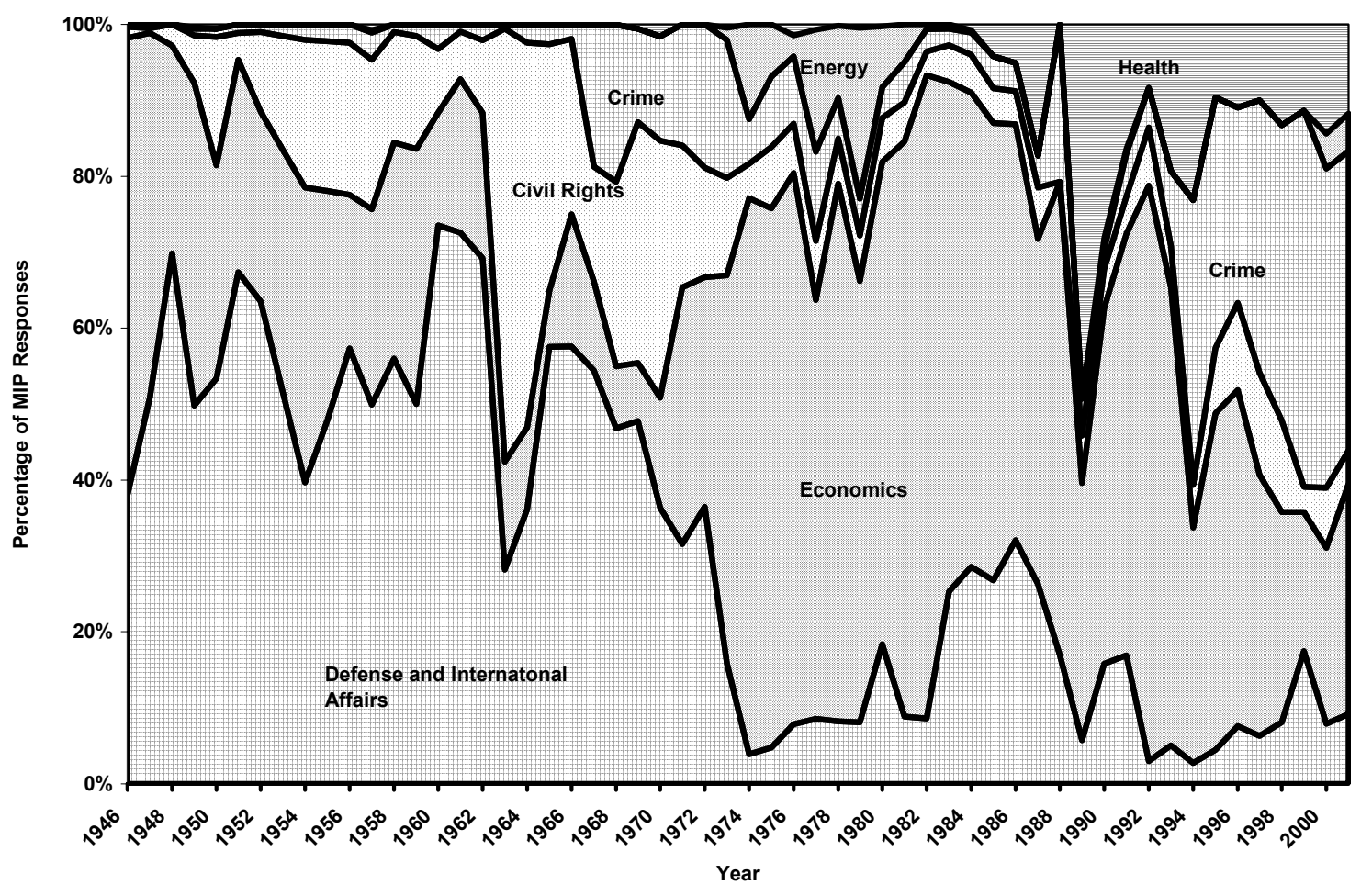

\section{Methods and Findings}

Our methodology is simple. We simply correlate the proportion of respondents in a category for the Most Important Problem data with the incidences of policy activities in the various policy channels of Table 1. We combined the Policy Agendas categories of Defense and international Affairs into a single category, because there was no reason to think that the public could distinguish these.

Our approach should become clear by focusing on a single example. Table 3 presents a table of correlations for Congressional bill introductions and MIP data. Each entry is a correlation between the bills introduced on a particular category and the proportion of respondents in a category for MIP surveys, across years. While the off-diagonals may be analyzed with profit (see Jones and Baumgartner 2004), here we focus only on the diagonal cells of the matrix. These correlations represent the correspondences between public priorities and bill introductions for comparable topics. We won't dally at this time to analyze the patterns in this table, except to note the high variability in correspondence across issues. In economics, health, agriculture, the environment, foreign trade, and defense, there is a very high correspondence between public priorities and bill introductions by congressmen. In most other areas, the correspondence is paltry, and occasionally even negative (such as is the case for welfare). 
Table 3: Correlations between Most Important Problem Questions and Bill Introductions, 1947-2001, by Major Topic Category

\begin{tabular}{|c|c|c|c|c|c|c|c|c|c|c|c|c|c|c|c|c|c|c|}
\hline & Econ & CRts & Heal & Agri & Labr & Educ & Envi & Ener & Tran & Crim & Welf & Hous & Com & Defl & SciT & ForT & Govo & PubL \\
\hline Economics & 0.65 & -0.27 & -0.15 & -0.15 & 0.09 & -0.09 & -0.09 & 0.45 & 0.18 & -0.21 & -0.22 & -0.03 & -0.11 & -0.29 & -0.13 & -0.07 & 0.05 & 0.33 \\
\hline Civil Rights & -0.02 & 0.02 & -0.05 & -0.18 & 0.14 & 0.18 & -0.08 & 0.21 & -0.31 & 0.16 & 0.06 & -0.26 & -0.37 & -0.13 & 0.11 & -0.03 & 0.36 & -0.02 \\
\hline Health & 0.22 & -0.40 & 0.57 & -0.46 & -0.27 & 0.52 & 0.49 & 0.09 & -0.24 & 0.48 & 0.82 & -0.23 & -0.17 & -0.77 & -0.48 & 0.62 & 0.46 & -0.02 \\
\hline Agriculture & -0.18 & 0.22 & -0.29 & 0.54 & 0.06 & -0.23 & -0.42 & -0.02 & 0.41 & -0.34 & -0.40 & 0.10 & 0.42 & 0.39 & 0.58 & -0.32 & -0.37 & 0.04 \\
\hline Labor & -0.09 & -0.04 & -0.01 & 0.10 & 0.26 & 0.17 & -0.15 & 0.05 & 0.03 & 0.29 & 0.02 & 0.18 & 0.05 & -0.02 & -0.03 & -0.04 & -0.13 & 0.00 \\
\hline Education & -0.36 & 0.47 & -0.16 & -0.24 & -0.03 & 0.04 & -0.03 & -0.15 & -0.21 & -0.12 & -0.18 & -0.04 & -0.18 & 0.42 & 0.11 & -0.19 & -0.09 & -0.12 \\
\hline Environment & 0.12 & -0.30 & 0.52 & -0.34 & -0.18 & 0.20 & 0.56 & -0.07 & -0.17 & 0.37 & 0.61 & -0.05 & 0.00 & -0.52 & -0.40 & 0.47 & 0.11 & -0.07 \\
\hline Energy & 0.75 & -0.48 & -0.06 & -0.18 & -0.17 & -0.24 & -0.03 & 0.74 & 0.17 & -0.10 & -0.02 & -0.02 & -0.15 & -0.56 & -0.24 & -0.07 & 0.57 & 0.38 \\
\hline Transportation & -0.45 & 0.46 & -0.46 & 0.24 & 0.28 & -0.40 & -0.19 & -0.23 & -0.14 & -0.36 & -0.61 & 0.09 & -0.06 & 0.78 & 0.47 & -0.46 & -0.27 & -0.20 \\
\hline Crime & 0.21 & -0.23 & 0.22 & -0.43 & -0.21 & 0.22 & 0.17 & -0.10 & -0.26 & 0.60 & 0.50 & 0.01 & -0.27 & -0.47 & -0.50 & 0.21 & 0.16 & -0.08 \\
\hline Welfare & 0.26 & 0.07 & -0.39 & -0.17 & 0.05 & -0.46 & -0.11 & 0.52 & 0.02 & -0.14 & -0.38 & 0.23 & -0.27 & 0.09 & 0.00 & -0.43 & 0.21 & 0.21 \\
\hline Housing & -0.14 & 0.03 & 0.08 & 0.13 & -0.11 & -0.36 & 0.04 & -0.17 & -0.10 & 0.05 & -0.18 & 0.13 & 0.10 & 0.18 & -0.03 & -0.13 & -0.15 & -0.25 \\
\hline Commerce & 0.73 & -0.59 & 0.18 & -0.23 & -0.23 & 0.00 & 0.09 & 0.23 & -0.07 & -0.06 & 0.27 & -0.26 & -0.10 & -0.60 & -0.30 & 0.31 & 0.10 & 0.08 \\
\hline $\begin{array}{l}\text { Defense \& Int. } \\
\text { Affairs }\end{array}$ & -0.42 & 0.33 & -0.27 & 0.56 & 0.31 & -0.33 & -0.14 & -0.31 & 0.12 & -0.46 & -0.44 & 0.30 & 0.34 & 0.72 & 0.31 & -0.26 & -0.45 & -0.15 \\
\hline $\begin{array}{l}\text { Science and } \\
\text { Tech }\end{array}$ & 0.01 & -0.17 & 0.22 & -0.28 & -0.04 & 0.23 & 0.21 & -0.32 & -0.29 & 0.07 & 0.32 & -0.24 & -0.24 & -0.14 & -0.02 & 0.24 & 0.16 & -0.20 \\
\hline Foreign Trade & 0.01 & -0.16 & 0.61 & -0.21 & -0.36 & 0.46 & 0.31 & -0.32 & -0.11 & -0.01 & 0.48 & -0.38 & 0.00 & -0.30 & -0.09 & 0.69 & -0.11 & -0.10 \\
\hline Gov't Oper & -0.52 & 0.61 & -0.49 & 0.36 & 0.28 & -0.30 & -0.38 & -0.16 & 0.12 & -0.17 & -0.58 & 0.20 & 0.06 & 0.75 & 0.31 & -0.52 & -0.25 & -0.03 \\
\hline Public Lands & -0.53 & 0.27 & -0.24 & 0.62 & 0.28 & 0.08 & -0.32 & -0.36 & 0.31 & -0.08 & -0.32 & 0.19 & 0.47 & 0.55 & 0.42 & -0.33 & -0.30 & -0.10 \\
\hline
\end{tabular}


Table 4: Correlations Between MIP and Policymaking Channels by Issue Area

\begin{tabular}{|c|c|c|c|c|c|c|c|c|c|c|c|}
\hline Major Topic & $\begin{array}{l}\text { State of } \\
\text { the } \\
\text { Union- } \\
\text { MIP }\end{array}$ & $\begin{array}{l}\text { Hearings- } \\
\text { MIP }\end{array}$ & $\begin{array}{l}\text { Investigative } \\
\text { Hearings- } \\
\text { MIP }\end{array}$ & $\begin{array}{l}\text { Legislative } \\
\text { Hearings-MIP }\end{array}$ & $\begin{array}{l}\text { NY } \\
\text { Times- } \\
\text { MIP }\end{array}$ & $\begin{array}{l}\text { Bills- } \\
\text { MIP }\end{array}$ & $\begin{array}{l}\text { Executive } \\
\text { Orders- } \\
\text { MIP }\end{array}$ & $\begin{array}{l}\text { Statutes } \\
\text {-MIP }\end{array}$ & $\begin{array}{l}\text { Cong. } \\
\text { Quarterly- } \\
\text { MIP }\end{array}$ & $\begin{array}{l}\text { Solicitor } \\
\text { General } \\
\text { Briefs- } \\
\text { MIP }\end{array}$ & $\begin{array}{l}\text { By } \\
\text { Request } \\
\text { Bill } \\
\text { Intros- } \\
\text { MIP }\end{array}$ \\
\hline Economics & .34 & .81 & .76 & .76 & .26 & .65 & .07 & .30 & .23 & -.24 & .13 \\
\hline Civil Rights & .14 & .27 & .45 & -.20 & .75 & .02 & .06 & -.20 & .22 & .55 & -.46 \\
\hline Health & .31 & .59 & .50 & .45 & .54 & .57 & 15 & .36 & .22 & .22 & .16 \\
\hline Agriculture & .65 & .15 & .37 & .33 & .42 & .54 & .28 & .06 & .50 & .03 & -.05 \\
\hline Labor & .15 & -.11 & .30 & -.08 & .53 & .26 & -.02 & -.18 & .18 & .45 & .10 \\
\hline Education & .70 & .35 & .24 & -.29 & -.24 & .04 & .00 & .26 & -.08 & .33 & .20 \\
\hline Environment & .41 & .63 & .51 & .58 & .40 & .56 & .37 & .28 & .31 & .07 & -.30 \\
\hline Energy & .52 & .76 & .74 & .69 & .71 & .74 & .67 & .38 & .35 & -.11 & .17 \\
\hline Transportation & .30 & -.15 & -.03 & .06 & .09 & -.14 & -.05 & .10 & -.13 & -.05 & -.09 \\
\hline Law and Crime & .53 & .41 & .38 & .47 & .28 & .60 & .16 & .22 & .00 & .07 & .02 \\
\hline Welfare & .47 & .41 & -.21 & .17 & -.07 & -.38 & .09 & .30 & -.08 & .11 & -.21 \\
\hline Housing & .16 & .13 & .17 & .04 & .19 & -.13 & .22 & .07 & -.19 & * & -.16 \\
\hline Commerce & .28 & -.07 & .13 & -.24 & -.11 & .10 & .01 & -.16 & .04 & .09 & -.26 \\
\hline $\begin{array}{l}\text { Science \& Tech } \\
\text { Defense \& }\end{array}$ & .38 & .00 & -.10 & -.07 & .25 & -.02 & .12 & -.09 & .06 & -.04 & -.24 \\
\hline International & .42 & .40 & .36 & .58 & .73 & .72 & .01 & .53 & .20 & .04 & .15 \\
\hline Foreign Trade & .09 & .61 & .53 & .01 & .08 & .69 & .09 & -.18 & .18 & .17 & .39 \\
\hline Average correlation & 0.37 & 0.32 & 0.32 & 0.20 & 0.30 & 0.30 & 0.14 & 0.13 & 0.13 & 0.11 & -0.03 \\
\hline
\end{tabular}


Since we are interested here in variability in correspondences between public and governmental policy priorities, we extract the main diagonal from a series of tables prepared for the policy channels listed in Table 1 . This yields Table 4, where the columns of the table are just the main diagonals of the eleven tables that all look like Table 3 for bills. We have ordered the columns such that the policy channel with the most robust correspondence with public opinion (the president's state of the union speeches) is to the left, and that with the weakest is to the right (by-request bills). In the table, we have added columns for hearings that consider legislation and those that are investigatory in nature (all hearings not considering bills) - we study nine separate channels, but have split one channel, hearings, into two parts. We hypothesize that the latter will be more sensitive to public opinion.

Figure 2 presents this information in a simpler graphic form. Each bar on the graph represents the average correlation between public priorities and policy activity for a particular channel, across all issue areas. It is clear that the channels organize themselves into two groups. One consists of presidential state of the union speeches, congressional hearings, congressional bills, and New York Times stories; the other consists of executive orders, statutes, Congressional Quarterly stories (which follow policy activities in congress), Solicitor General briefs, and by-request bills (representing the president's legislative priorities).

Figure 2: Average Correlation between MIP and Institutional Channels, Across Major Policy Areas

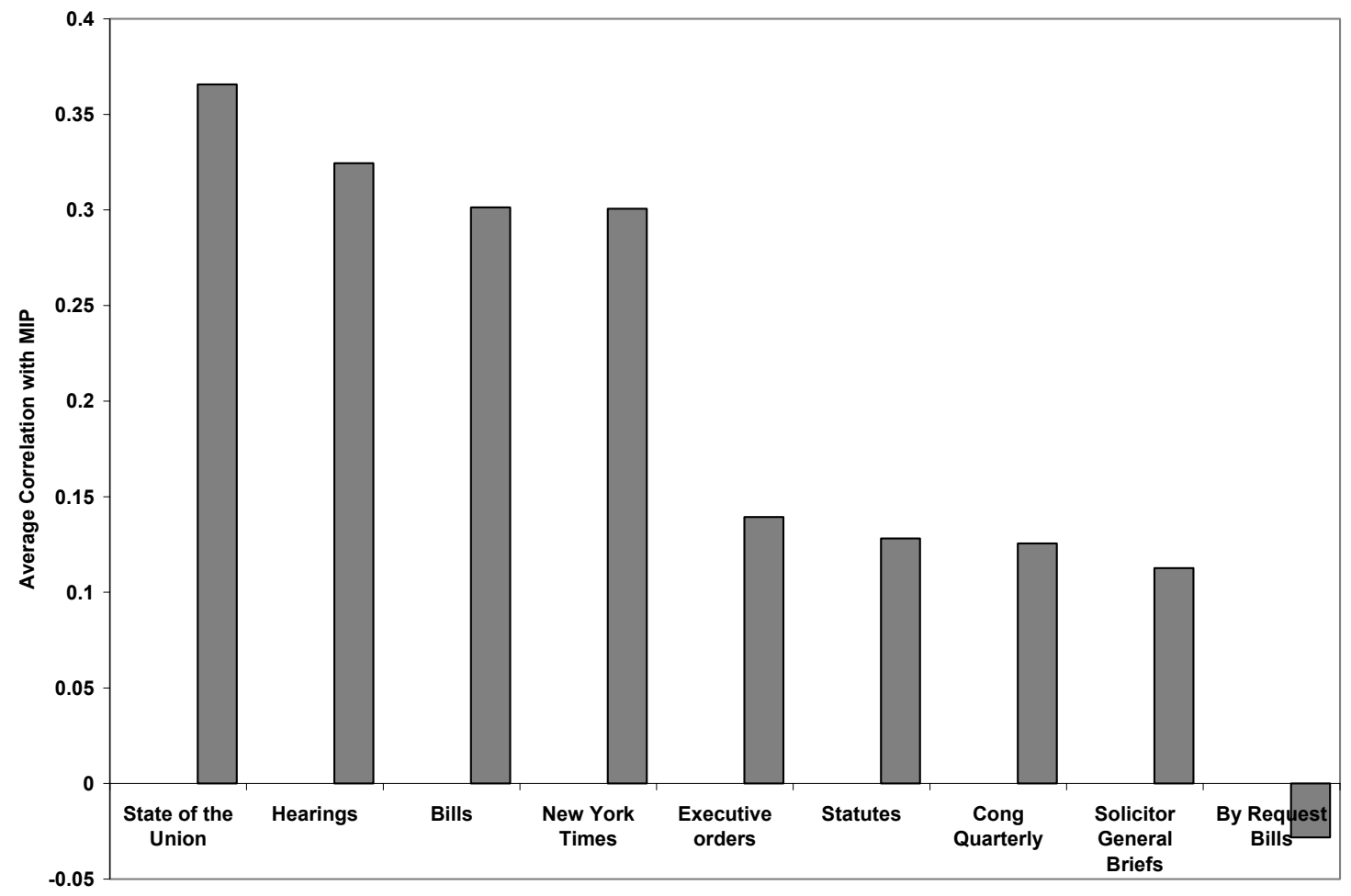


The groupings correspond reasonable closely to the expectations set out in Table 2, at least for the general groupings. That is, as we expected, the president's state of the union, hearings, bills, and media all displayed closer correspondence with public opinion than did the other channels. It is not really possible, however, to distinguish among these more remote policymaking channels (remote both in terms of transparency and friction), except for the president's legislative program (by-request bills), which has no relationship whatsoever with public opinion.

\section{Issue Importance and Correspondence}

Now we turn to the issue of correspondence between public opinion and policy actions across issues. Wlezien has cautioned that importance is not the same as salience, because an issue can be salient in the current discourse and not be a very important issue facing the nation (Wlezien 2005). Surely the issue of a 'culture of life' was salient in the American discourse in the furious debate over Terry Schiavo, but clearly this was an unimportant issue in the minds of most Americans. It should be clear that in the present study, we are far more interested in issue importance than issue salience. We ask whether there is a tighter correspondence between policy actions of government and variations in issue importance to citizens.

To study this, instead of averaging correlations down the columns of Table 4 , we average across the rows (we used only total hearings here). Then we ordered these averages for issues, with the largest first, and produced Figure 3. Issues of course may be of enduring importance to citizens, such as is the case for economics, or they may be of intense importance for a brief period of time, as the case for energy in the late 1970s. The way we have measured correspondence is insensitive to this, so long as policy actions match citizen concerns at the time they register on the MIP questionnaire.

Figure 3 indicates that there is substantial variability in opinion-policy correspondence across issue areas. The top issue areas contain few surprises. Energy, defense, economics, health and the environment are the top five; each has an average correlation of better than .34. At the other end of the ranking, policy activities in the realms of government operations, public lands management, commerce, transportation, and science and technology have negligible or actual negative correlations with opinion. Interestingly, welfare and housing have quite low associations as well.

Our aim here is a sweeping study of opinion-policy correspondence across policymaking channels and issues, so we cannot study the reasons for variability in the connections between opinion and policy across issues. We suspect, however, that where issues are less important, policymakers are much freer to incorporate other factors than public opinion when producing policy. 
Figure 3: Average Correlation Between MIP and Policy Areas, across Institutional Channels



\begin{tabular}{|c|c|}
\hline Policy Area & Averag \\
\hline Energy & 0.511 \\
\hline Defense \& International & 0.376 \\
\hline Economics & 0.37 \\
\hline Health & 0.37 \\
\hline Environment & 0.347 \\
\hline Agriculture & 0.298 \\
\hline Law and Crime & 0.285 \\
\hline Foreign Trade & 0.242 \\
\hline Civil Rights & 0.145 \\
\hline Labor & 0.144 \\
\hline Education & 0.137 \\
\hline Welfare & 0.055 \\
\hline Housing & 0.05 \\
\hline Science \& Tech & 0.023 \\
\hline Transportation & -0.008 \\
\hline Commerce & -0.017 \\
\hline Public Lands & -0.057 \\
\hline Government Operations & $-0.05 \varepsilon$ \\
\hline
\end{tabular}




\section{A Final Look at the Whole Picture}

Table 5 cross-classifies policy channels and policy issues by denoting whether the correlation reaches conventional levels of statistical significance. We use a one-tailed test, in effect dropping consideration of correlations that indicate that policy activities and public opinion move in different directions.

Rows are ordered such that the issue area with the greatest number of significant correlations across policy channels (energy) is at the top, and the issue with the lowest correspondence (here, housing) is at the bottom. There are some slight but substantively insignificant differences between using statistical significance as a criterion rather than the size of the average correlation.

One important facet of the system of correspondence we study is revealed by the table, however. Now statutes occupy an intermediate position between the most sensitive policy channels (the state of the union speeches, hearings, bill introductions, and media coverage) and the least sensitive.

Table 5: Significant Correlations between MIP and Major Policy Areas, across Institutions*

\begin{tabular}{|c|c|c|c|c|c|c|c|c|c|c|}
\hline Major Topic & $\begin{array}{l}\text { State of } \\
\text { the } \\
\text { Union }\end{array}$ & Hearings & $\begin{array}{l}\text { New } \\
\text { York } \\
\text { Times }\end{array}$ & Bills & Statutes & $\begin{array}{l}\text { Executive } \\
\text { Orders }\end{array}$ & $\begin{array}{l}\text { Solicitor } \\
\text { General } \\
\text { Briefs }\end{array}$ & $\begin{array}{l}\text { By } \\
\text { Request } \\
\text { Bills }\end{array}$ & $\begin{array}{l}\text { Cong } \\
\text { Quart }\end{array}$ & $\begin{array}{l}\text { Total } \\
\text { Significant }\end{array}$ \\
\hline Energy & 1 & 1 & 1 & 1 & 1 & 1 & & & & 6 \\
\hline Economics & 1 & 1 & 1 & 1 & 1 & & & & & 5 \\
\hline Health & 1 & 1 & 1 & 1 & 1 & & & & & 5 \\
\hline $\begin{array}{l}\text { Defense \& } \\
\text { International }\end{array}$ & 1 & 1 & 1 & 1 & 1 & & & & & 5 \\
\hline Environment & 1 & 1 & 1 & 1 & 1 & 1 & & & & 6 \\
\hline $\begin{array}{l}\text { Agriculture } \\
\text { Law and Crime }\end{array}$ & 1 & 1 & 1 & 1 & & 1 & & & 1 & 6 \\
\hline Foreign Trade & 1 & 1 & 1 & 1 & & & 1 & & & 5 \\
\hline & & 1 & & 1 & & & & 1 & & 3 \\
\hline Labor & & & 1 & 1 & & & & & & 2 \\
\hline Education & & 1 & & & 1 & & 1 & & & 3 \\
\hline Civil Rights & & & 1 & & & & 1 & & & 2 \\
\hline $\begin{array}{l}\text { Welfare } \\
\text { Science \& Tech }\end{array}$ & 1 & 1 & & & 1 & & & & & 3 \\
\hline Transportation & 1 & & & & & & & & & 1 \\
\hline Commerce & 1 & & & & & & & & & 1 \\
\hline Housing & 1 & & & & & & & & & 0 \\
\hline $\begin{array}{l}\text { Total } \\
\text { Significant }\end{array}$ & 11 & 10 & 9 & 9 & 7 & 3 & 3 & 1 & 1 & \\
\hline
\end{tabular}

${ }^{*}$ One-tailed test at 0.05 . 
Just as important, activity in the lawmaking area corresponds to activity in the higher correspondence group of channels. Statute activity is significantly correlated with the high-importance issue areas of energy, economics, heath, defense and international affairs, and the environment. We rated lawmaking as being subject to considerable institutional friction (requiring the collaboration of both legislative branches and the executive branch), but of high transparency in Table 2. By the measure of Table 5, lawmaking falls about where it should.

\section{Do We Observe Only Symbolic Responsiveness?}

One might wonder if we are simply distinguishing between symbolic acts and real policymaking. It may be easy to discuss relevant topics in speeches or to introduce meaningless bills on the topic, but it can be much harder to do the legislating. At one level, this is just a restatement of our friction hypothesis, but if hearings, or bills, or speeches are never meant to lead to policymaking, then one has a different kettle of fish entirely.

Studying policy processes at the aggregate level as we do here can never demonstrate conclusively whether the symbolic politics hypothesis is right-or, rather, whether real policymaking occurs even though symbols are also produced for the consumption of the public. We can do a rudimentary test by assuming that public opinion is connected to lawmaking through intermediaries, particularly hearings and bill introductions. Of course no law can be passed without a bill and (usually) a hearing. But that is not the question. The issue is whether lawmaking happens more or less independently of hearings and bills, and, hence public opinion (since these two channels are tied fairly tightly to opinion-at least for salient issues). The lower correlations for lawmaking may simply reflect the added institutional friction that must be overcome.

We instituted a rough but simple test. If we think of a translation process as occurring along a causal path, as diagrammed below, we can reproduce correlations implied by that path and compare them to the correlations we actually observe between MIP and Statutes. Table 6 does these calculations.

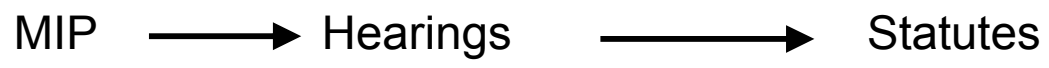

The correspondences between MIP responses and lawmaking for the issues that are generally most important to the public are quite impressive, with little slippage for energy, economics, health, and the environment. These findings suggest that hearings, far from being a symbolic act that do not serve to translate public pressures into substantive public policies, actually do serve their civics function of investigating situations that warrant legislation.

\footnotetext{
${ }^{1}$ Less convincingly, executive orders fall below statutes in ranking, but above the less transparent channels of solicitor general briefs and CQ stories, an intermediate position implied by Table 2 .
} 
Table 6: Public Opinion and Lawmaking Mediated by Hearings

\begin{tabular}{|c|c|c|r|r|r|}
\hline Major Topic & $\begin{array}{c}\text { Hearings- } \\
\text { MIP }\end{array}$ & $\begin{array}{c}\text { Hearings } \\
\text {-Statutes }\end{array}$ & $\begin{array}{c}\text { Reproduced } \\
\text { correlation }\end{array}$ & $\begin{array}{c}\text { Actual } \\
\text { MIP- Statues }\end{array}$ & $\begin{array}{r}\text { Difference } \\
\text { (slippage) }\end{array}$ \\
\hline Energy & $\mathbf{0 . 7 6}$ & $\mathbf{0 . 4 3}$ & 0.33 & $\mathbf{0 . 3 8}$ & 0.05 \\
\hline Economics & $\mathbf{0 . 8 1}$ & $\mathbf{0 . 4 4}$ & 0.36 & $\mathbf{0 . 3}$ & -0.06 \\
\hline Health & $\mathbf{0 . 5 9}$ & $\mathbf{0 . 6 4}$ & 0.38 & $\mathbf{0 . 3 6}$ & -0.02 \\
\hline Defense \& International & $\mathbf{0 . 4}$ & $\mathbf{0 . 4 6}$ & 0.18 & $\mathbf{0 . 5 3}$ & 0.35 \\
\hline Environment & $\mathbf{0 . 6 3}$ & $\mathbf{0 . 5 5}$ & 0.35 & $\mathbf{0 . 2 8}$ & -0.07 \\
\hline Agriculture & 0.15 & 0.13 & 0.02 & 0.06 & 0.040 \\
\hline Law and Crime & $\mathbf{0 . 4 1}$ & $\mathbf{0 . 3 1}$ & 0.13 & 0.22 & 0.093 \\
\hline Foreign Trade & $\mathbf{0 . 6 1}$ & -0.19 & -0.12 & -0.18 & -0.06 \\
\hline Labor \& Employment & -0.11 & 0.2 & -0.02 & -0.18 & -0.16 \\
\hline Education & $\mathbf{0 . 3 5}$ & $\mathbf{0 . 5 2}$ & 0.18 & $\mathbf{0 . 2 6}$ & 0.08 \\
\hline Civil Rights & $\mathbf{0 . 2 7}$ & -0.29 & -0.08 & -0.2 & -0.12 \\
\hline Welfare & $\mathbf{0 . 4 1}$ & $\mathbf{0 . 5 1}$ & 0.21 & 0.3 & 0.09 \\
\hline Science \& Technology & 0 & $\mathbf{0 . 4 2}$ & 0 & -0.09 & -0.09 \\
\hline Transportation & -0.15 & $\mathbf{0 . 3 8}$ & -0.06 & 0.1 & 0.16 \\
\hline Commerce \& Finance & -0.07 & $\mathbf{0 . 5 3}$ & -0.04 & -0.16 & -0.12 \\
\hline Housing & 0.13 & 0.22 & 0.03 & 0.07 & 0.04 \\
\hline
\end{tabular}

Lawmaking activities on defense seem different. The intermediate step of hearings is not sufficient to account for the connection between MIP and laws. Perhaps the urgency of defense generates lawmaking will fewer hearings than would be the case in domestic policy arenas. Finally, it is difficult to say much about the issues where actual correlations are low, as slippage can be generally low there and tell us nothing.

It seems likely that the generally lower correlations between MIP and lawmaking are due to the fact that lawmaking is a 'downstream' activity - that is, there are intermediate steps that must be accomplished before statutes are passed-and institutional friction is added in the process. 


\section{Conclusions}

In this paper we pursue a new approach to the issue of representationby asking whether the policy activities of government correspond to the priorities of the public. We move in a significant new direction in three ways: by recognizing that representation cannot occur if policymakers and the public prioritize problems differently - they must at least be on the same page; by incorporating the friction of governing institutions into the model-friction should attenuate the correspondence between public and policy; and by incorporating the notion of the transparency of the action into the mix-highly transparent actions are more subject to public scrutiny and potential electoral accountability.

We cannot speak to the reasons for the correspondence. It can be that both policymakers and the public detect similar problems in the environment, or it is possible that the concerns of the public are transmitted to policymakers, and they subsequently act. In at least one issue area, economics, the latter mechanism is more likely (Jones and Baumgartner 2005: Chapter 8). Nor can we say how much feedback is occurring from policymakers to the public.

More importantly, we cannot speak to the specifics of the debates concerning whether current political leaders ignore public opinion in forging policies (Jacobs and Shapiro 2000; Hacker and Pierson 2005). First, we observe connections across long periods of time, whereas the debate today focuses on quite current behaviors. Second, for most students of representation, correspondence has centered either on general ideology (does liberal opinion lead to liberal policies?) or on solutions that do not incorporate public priorities (is the public for or against President Bush's social security privatization plan?).

Both of these framings of the issue of representation are really quite incomplete, and that is where our study can add clarity. The potential correspondence between ideology and directional (liberal-to-conservative) policies masks the particular choice of policies. A liberal public may prioritize health care but a liberal government may be producing environmental regulation; we won't know if we focus only on ideology. (If we focus on how liberal or conservative congressional voting behavior is, we miss both priorities and friction.)

Similarly, an ideal study of representation would include both priorities and policy solutions. In the 1980 s people ranked the economy as consistently the most important problem facing the nation. They got hearings and action, mostly in the form of tax cuts (and then tax increases as the budget deficit burgeoned), tax reform, and budget cuts. Whether this is the set of solutions they desired is something else. They may have; or they may not have; here we simply point out that the correspondence between public priorities is a worthy but almost completely ignored area of study. 


\section{References}

Erikson, Robert, Michael MacKuen, and James Stimson. 2002. The MacroPolity. Cambridge: Cambridge University Press.

Feeley, T. Jens, Heather Larsen, and Bryan D. Jones. Recorded MIP Dataset Codebook. Seattle: Policy Agendas Project.

Jones, Bryan D. and Frank R. Baumgartner. 2005. The Politics of Attention. Chicago: University of Chicago Press.

Jones, Bryan D. and Frank R. Baumgartner. 2004. Representation and Agenda Setting. Policy Studies Journal 32: 1-24.

Hacker, Jacob and Paul Pierson. 2005. Off Center. New Haven: Yale University Press.

Jacobs, Lawrence and Robert Shapiro. 2000. Politicians Don't Pander. Chicago: University of Chicago Press.

Soroka, Stuart, and Christopher Wlezien. In press. Opinion-Policy Dynamics: Public Preferences and Public Expenditures in the United Kingdom. British Journal of Political Science.

Sulkin, Tracy. 2005. Issue Politics in Congress. Cambridge: Cambridge University Press.

Wlezien, Christofer. 2005. On the Salience of Political Issues. Electoral Studies 25: 